INDEPENDENT JOURNAL OF MANAGEMENT \& PRODUCTION (IJM\&P)

http://www.ijmp.jor.br

v. 12, n. 4, May-June 2021

ISSN: 2236-269X

DOI: 10.14807/ijmp.v12i4.1351

\title{
THE IMPACT OF ABSENTEEISM AND THE RELATIONSHIP WITH EMOTIONAL ABSENCE BASED ON INDIVIDUAL STORIES
}

\author{
Leandro Marcucci \\ UNIVALI, Brazil \\ E-mail:lemarcucci@gmail.com \\ Ruan Carlos dos Santos \\ Centro Universitário UNIAVAN, UNIVALI, Brazil \\ E-mail:ruan_santos1984@hotmail.com \\ Submission: 5/25/2020 5:51:40 PM \\ Revision: 7/3/2020 3:57:22 PM \\ Accept: 7/14/2020 10:13:29 AM
}

\section{ABSTRACT}

The relationship between the concepts of stress, mental illness and burnout syndrome seems to be indistinguishable when it comes to work leave by individuals who present specific and common symptoms. Recent research has shown an increase in absenteeism as a pandemic in society, one of the main problems faced by organizations, the consequences of illness generated by lack of emotional health, and the emergence of such symptoms arising from these relationships. This study analyzes the discourse of individuals diagnosed with burnout syndrome, seeking to identify the multiple relationships between the underlying symptoms and emotional health problems, a new concept discussed by theorists in recent years. For research purposes, elements of qualitative methodology were used. The narratives were analyzed considering psychoanalysis, and supported by the social interpretation of the reports. The results showed a significant trend towards a relationship between the concepts, the subject studied and the stories told in the interviews, leading us to reflect on the emotional impact of these relationships on work environments, individuals and society.

Keywords: Contemporary management, Absence of emotional health, impact of the Burnout syndrome. 
DOI: 10.14807/ijmp.v12i4.1351

\section{INTRODUCTION}

The reflections on the theme of this paper seek to outline a historical path of studies on absenteeism, by bringing the relationship between this theme and the concepts of stress - illness - burnout syndrome and lack of emotional health. Approaches have been studied in this context over the last 70 years (Robbins, 2004) of pressures for productivity and goals that are often impossible to achieve, from stressful environments to profiles of bosses and managers with repressive and controlling characteristics, increasingly increasing the difficulties of the wellbeing of individuals in organizations.

With absenteeism as one of the main organizational problems, the consequences of illness generated by the absence of physical and mental health arising from these relationships have become undeniable. (Alvesson, 2012). In addition, there would be in the contemporary world an incessant search for productivity, which would generate a competitiveness based on the systematic and positivist objectivity of the institutions, leaving the issues related to the problems of the so-called corporate well-being to the studies of subjectivity.

Subjectivity studies include the subthemes related here to stress, illness, burnout syndrome, up to the most recent term, which directs this study to an innovative theme, "absence of emotional health", which would directly influence individuals in the field of emotions, by bringing severe impacts especially when they bring this absence to the surface as a social pandemic (Leiter, 2013).

For the applied sciences of administration, studying the theme of absenteeism from the notion of absence of emotional health means bringing a contemporary and extremely recent perspective to the area, which began in 2006 in Europe, more precisely in Germany, with the creation of a model of the concept of absence of emotional health in organizations, still little used (Kraft, 2006).

In Brazil, there was little research on the theme of lack of emotional health in organizations until the years 2009, mainly due to the difficulty of access to this type of information, since the organizations did not want to show that their workers presented some discomfort in relation to health (Zanatta, 2015). 
DOI: 10.14807/ijmp.v12i4.1351

\section{LITERATURE REVIEW}

\section{1. $\quad$ Recent Studies}

In Brazil, the works of multi-level research of 1) Canesqui (2010), with themes and approaches of social and human sciences in health in academic production from 1997 to 2007; 2) Nascimento (2011) referring to the studies of the psychic repercussions caused by work environments, in 730 articles that analyze citations related to all situations in which the collaborator and organizations influence each other; 3) Muniz (2014) with the theme emotional health and stress control of 240 municipal guards in the State of São Paulo.

Mention is also made of the recent work of researchers from other countries, which began almost at the same time, among them: 1) In England, Prosser (2012), when writing about the relationship between stress and job satisfaction, in a study with thirty health professionals; 2) In Mexico, Martinez (2013), when studying the relationship between the dynamics of emotional health associations, an analysis of the causal relationship between emotional health and job satisfaction; 3) In the United States, Glina (2008), when they discussed and analyzed 150 cases of workers who had been removed and treated in reference centers, with diagnoses based on daily practices in relation to work and mental health; and 4) In Spain, Simón (2013), when they studied the factors influencing emotions in six hundred and forty-two Spanish workers, adolescents, and those aged up to eighteen years.

The most recent research involving the key concepts for this research presents related themes such as: "illness and psychic health", "physical and mental exhaustion of the worker", "stress and productivity". For several authors, the intention is to understand the dynamics of these processes: Stein (2009), Assunção (2007), Arnaud (2012), Archer (2000), Alves (1996), Bachelard (1996), Brotheridge (2002), Calheiros (2010), Chanlat (1994), Erickson (1997), Fiker (2006), Fredrickson (2005/2006), Freudenberger (1974), Harvie (2006), Linstead (1992), Minayo (2002), Pugliesi (1999) and Robbins (2009) sought through complex relationships, to explain the social nuances that affect human beings in their individual and social anxieties (Braverman, 2012).

If on one hand individuals are charged for the systems that society creates, there is always the opposite, thinkers who criticize the existing systems and suggest new constructs (industrial models and alternative societies; productivity and control; pressure, goals and results) (Routledge, 2005). At the end of the 19th century, scholars of the human sciences appropriated these analyses in order to create complementary theories for exact science 
DOI: 10.14807/ijmp.v12i4.1351

researchers, which opened up new horizons and perspectives for the social sciences, and a little later for the applied social sciences (Neuman, 2013).

Besides these, classical authors through their works have always been in search of explanations for the emotional dilemmas of individuals, by raising questions about the role and function of man as a social being: Freud (1915) when he produced "Malaise in Civilization"; Heidelberg (1953) with "Mythology of Emotions", Dejours in "The Psychic Load of Work" (1980) and "Psychodynamics of Work" (1994) through his significant concepts; besides Ehrenberg (1998) when he wrote "The fatigue of work" and; Kraft (2006) when he developed a model of recognition of emotional health risk at work.

\subsection{Emotions, health and organizational behavior}

The concept of emotional health is linked to the habits of life that characterize a healthier way of living (Vilela, 2007). Well-being in life is a concept that encompasses several dimensions: emotional, physical, spiritual, social, family and professional, and includes responsibility for one's own health, seeking a more balanced lifestyle (Health Ministry, 2007). In addition, the family history, the environment in which you live, the health care you receive are also decisive.

Emotional health is the balance of psychic functions, which reveals itself in the ability to control and manage emotions, resulting in a feeling of well-being and the absence of emotional disorders (Tamayo, 2004). Not having emotional imbalance does not necessarily mean one is walking towards full health. It is not only physical factors that affect your ability to stay healthy: the lack of defined goals, empty emotional life and out of control anxiety can also generate a state of imbalance (Dejours, 2004).

When the individual is in a condition of frequent psychic and physical imbalance, together with the problems faced daily in organizations, the probability of a breakdown is accentuated. In the studies that served as the basis for this work, in a common way, behaviors are cited that frequently present themselves in companies: frequent conflicts with colleagues and managers, the lack of autonomy in relation to time itself and the feeling of having very little used capacities fills a perfect picture for the appearance of stress and burnout syndrome, which accelerates the appearance of symptoms such as muscular tension, nervous gastritis, heart problems, depression, insomnia and generalized anxiety disorders.

It is important to emphasize some definitions about organizational behavior because, through it, one can better understand human behavior. Without the understanding of this 
INDEPENDENT JOURNAL OF MANAGEMENT \& PRODUCTION (IJM\&P)

http://www.ijmp.jor.br

v. 12, n. 4, May-June 2021

ISSN: 2236-269X

DOI: 10.14807/ijmp.v12i4.1351

behavior, it is impossible to understand the needs that motivate people to develop their tasks well. For this reason, Wagner and Hollenbeck (2002), who discuss organizational behavior as "a field of study aimed at predicting, explaining, understanding and modifying human behavior in the context of companies", are used.

Behaviors and attitudes related to the absence of emotional health in organizations need to be studied and analyzed by three determining factors: individuals, groups and structure, so that they have positive results and more effective people, that is, how these behaviors affect the performance of these companies (Robbins, 2002). It is noted that this relationship affects directly on employees and acts on the needs, personality, teamwork capacity, ambitions, and dreams, of each of the members of an organization. If individual needs do not meet the needs of the organization, the result of this interaction can be seen in low performance and low motivation teams.

Emotions were cited by McGregor (2002) as instincts associated with emotion and, which would explain some actions within organizations: Escape instinct that provokes, among others, the emotion of fear; Fighting instinct that originates the emotion of anger; Paternal instinct that leads to tenderness; Curiosity instinct that originates the emotion of admiration; Self-affirmation instinct that leads to the emotional expression of pride, being able to justify the pride of social class and cultural level; Instinct of self-humiliation that originates the emotion of submission before people of greater capacity; Gregarious instinct that leads to the emotion of loneliness; Property instinct, simply for the pleasure of having; Food instinct that provokes the emotion of hunger; justifies the purchase of food and drink.

Now, if behaviors are linked to emotions and are closely linked to the needs, needs or desires that people can present at each moment, through behavioral theories we could explain the decisions related to work. As the subjectivity and complexity in the situations is much accentuated, the rationality is limited, there is a relativity and imperfection in the decisions because the chosen alternative never allows a perfect or complete fulfillment of the objectives pursued, which happens with the absence of emotional health and burnout syndrome.

If for administrative rationality the behavior of individuals in organizations can be oriented to achieve objectives, in the complexity and subjectivity of human emotions, this does not become so simple, since it would also take into account affectivity and relational capacity, in which the behavior of an individual is proportional to his affectivity, and can be high or low. 
DOI: 10.14807/ijmp.v12i4.1351

In this way, the affective aspect would have a profound influence on the development of employees in companies (Lima, 1998).

\subsection{The impact of dissatisfaction on work}

Indicators of dissatisfaction in the work environment, such as turnover and absenteeism, have grown significantly over the years despite the efforts made to contain these impacts (Calheiros \& Rodrigues, 2010). Despite the numerous advances observed in the field of organizational psychology by authors such as Dejours (1980) and Bleger (1996), a growing trend of oppressive workplaces can be observed (Schöttner, 2008).

In addition, there is a growing number of working arrangements in which the employee is forced to accept the performance of activities that are not of his or her preference. The purpose of these changes is to reduce operating expenses that result from organizational restructuring that usually adds functions and increases demand on the worker (Neuman, 2003).

This situation generally determines a drop in the quality of services provided by individuals, increasing their dissatisfaction with their work. This negative scenario related to the work context has favored the absence of emotional health at work and the occurrence of a significant number of diseases and syndromes such as: hypertension, diabetes, major depression and burnout syndrome (Iacovides, 2003).

Another significant factor is the relationship between job satisfaction and worker health, since with the increase in the level of dissatisfaction at work increases the use of medicines, alcohol and drugs by individuals (Limongi-France \& Arellano, 2002). This dissatisfaction originates in the imposition of performing a meaningless and non-involving function for the employee, and mainly because the employee does not know the usefulness of his work for the entire organization. This causes the employee a feeling of devaluation, both in relation to remuneration and in relation to the opportunity to develop their skills, autonomy and responsibilities in the company (Dejours, Jayet \& Abdoucheli, 1994).

Even if there is an initial, desire to contribute, as time goes by, this will diminish because of the work context in which most workers contribute in a small way (Lima, Mendonça \& Lima-Filho, 2009). This set of factors, such as: negligible work, accumulation of unpleasant activities and unfavorable work context, can lead to absence of emotional health and the manifestation of syndromes such as burnout (Zanatta, 2015). Corroborating this idea, Dejours (2015) states that the worker is made up of what he does, just as what he does constitutes what he is. 
DOI: 10.14807/ijmp.v12i4.1351

In this way, understanding this reciprocity makes it possible to consolidate a clinical practice capable of signifying one's own work. In this way, it is significant to investigate in the worker's life history possible events in which the worker has experienced traumas that may manifest themselves through adverse situations in the context of work.

The concept of Robbins (2009) for job satisfaction is something that extrapolates the context of the company itself. In this way, it is also necessary to measure outside the work environment. It is also in most of these companies, with little interest in the overall context of the worker and his satisfaction at work, that the main problems are observed.

\subsection{The Kraft model}

Within an organization, it is necessary to understand people's needs, discover their individual and professional goals, and then adjust them to the organization and vice versa. Do some personality types adapt more easily to certain types of work? In an attempt to answer, Robbins (2002) states that personality is the internal dynamic organization of those psychological systems of the individual that determine their specific adjustment to the environment. For Soto (2002) personality also includes intellectual, affective, impulsive, physiological and morphological aspects.

Through the above, we can then begin to study the reasons that lead workers to withdraw, or absenteeism itself as a consequence of physical and emotional exhaustion, and what would be the causes that lead individuals to withdraw by burnout. The term Burnout (which in English means, "totally burned") interferes with the ability to lead a professional and personal life, happy, healthy and productive (Maslach, 2008).

Who is affected by this evil depends on each profession, but regardless of the areas in which they work, the first symptom that becomes evident is "discouragement", up to the last stage called "exhaustion" by specialists. The syndrome also reveals relationship problems and associated stress, decreasing physical resistance and especially mental and cognitive resistance, because professional demands exhaust the individual's resources at work, which suggests a reassessment of the way the work is performed, with the performance of functions considered "tedious" to the detriment of others more pleasant.

The concept of "Emotional Health" has been cited since the years 2007 in researches related to workers' health around the world (Leiter, 2013). In 2013, some authors began to study more closely the "Emotional Health at Work Syndrome", relating suffering - stress burnout - absenteeism, as inseparable. 
INDEPENDENT JOURNAL OF MANAGEMENT \& PRODUCTION (IJM\&P)

http://www.ijmp.jor.br

v. 12, n. 4, May-June 2021

ISSN: 2236-269X

DOI: 10.14807/ijmp.v12i4.1351

In a longitudinal study published in 2008, 4446 employees of a multinational company based on all continents were evaluated, and again after one year, the same aspects of this disorder were investigated, in order to know how the same participants who scored high in only three dimensions, for example, "exhaustion", and how it would be one year later.

The common indicator found in the survey was "a sense of injustice and a climate of favoring people who would not be prepared to receive rewards such as promotions or transfers. The study showed that professionals who saw the professional environment as impartial showed some improvement. However, the great result was the appearance of the "Emotional Health at Work Syndrome" in more than $20 \%$ of the interviewees. The pressure for goals and the excessive number of hours worked were pointed out as the main causes of poor health in workers.

Employees who experienced discouragement and pessimism but had not yet lost energy or efficiency were more likely to regain their spirits when they felt their superiors communicated well with them and kept them in important projects (Leiter, 2013). This was fundamental to the understanding of the company's health professionals, who used a cyclical diagnostic model entitled "Emotional Health Risk Recognition at Work Model" prepared by Ulrich Kraft, based on the concepts of Emotional Collapse and with an enormous tendency toward absenteeism and presents, in the elaboration of Ulrich Kraft - Emotional Health Risk Recognition Model, as shown in the table below.

Table 1: Emotional Health Risk Recognition Model - Kraft in 2006

\begin{tabular}{|c|l|l|}
\hline STAGE & \multicolumn{1}{|c|}{ CONCEPT } & \multicolumn{1}{c|}{ SYMPTOM } \\
\hline 01 & Need for self-assertion & $\begin{array}{l}\text { Doing everything perfectly, afraid of making mistakes and } \\
\text { compulsion for performance; }\end{array}$ \\
\hline 02 & Intensified dedication & Intensify things and try to do everything yourself; \\
\hline 03 & Mischief with oneself & Professional life takes up almost all the time; \\
\hline 04 & Avoid conflitos & The person fears a crisis and the first physical problems arise; \\
\hline 05 & Interpreter valors & $\begin{array}{l}\text { Isolation, denial of one's own needs and self-esteem is measured by } \\
\text { work; }\end{array}$ \\
\hline 07 & Denies problems & The person becomes intolerant and considers others incapable; \\
\hline 08 & Collection & $\begin{array}{l}\text { Signs such as irritation, discouragement and alcohol and drug abuse } \\
\text { can occur; }\end{array}$ \\
\hline 09 & Depersonalization & $\begin{array}{l}\text { Fear, shyness and apathy. He blames the world and feels more and } \\
\text { more useless; }\end{array}$ \\
\hline 10 & Indoor Empty Sensation & $\begin{array}{l}\text { He devalues everyone and himself; he abandons personal needs; he } \\
\text { stops making plans; }\end{array}$ \\
\hline 11 & Depression & $\begin{array}{l}\text { Indifference, lack of hope and extreme tiredness; life loses its } \\
\text { meaning; }\end{array}$ \\
\hline 12 & $\begin{array}{l}\text { Emotional Health } \\
\text { Syndrome }\end{array}$ & $\begin{array}{l}\text { One perceives oneself as a dead end; there is total emotional, physical } \\
\text { and psychic collapse. }\end{array}$ \\
\hline
\end{tabular}

Source: prepared by the authors (2018). 
DOI: 10.14807/ijmp.v12i4.1351

This chart represents the interdisciplinary context used during the work, by using the clinical interview technique, the psychoanalytical interpretation and social analysis of the elements of the speeches presented. After the initial practical work, Conde (2009) recommends that the analysis of the constructed texts be continued, in the following sequences: a) interpretation, b) analysis and; c) articulation between the analysis and the interpretation, suggesting a narrative articulation of the research results. It is important to emphasize the importance of the use of Freudian psychoanalytical concepts of - Absence of Psychic Health and Inner Suffering; and the concept of Emotional Collapse with an enormous tendency towards absenteeism and presents, in the elaboration of Ulrich Kraft - Model of Recognition of Emotional Health Risk at Work.

Once the interpretative procedures covering the work of the text in a global manner had been finalized, the steps concerning the analysis procedures were initiated.

\subsubsection{Description of research participants}

The subjects participating in the research captured in the scope of the researcher's intervention are characterized by female patients, in working age considered productive (from 20 to 50 years) and of Brazilian nationality.

Table 2: List of Respondents for Research

\begin{tabular}{|c|l|l|l|}
\hline $\begin{array}{c}\text { Nomenclature } \\
\text { (Interviewed) }\end{array}$ & \multicolumn{1}{|c|}{ Training } & \multicolumn{1}{|c|}{ Current profession } & $\begin{array}{c}\text { Name } \\
\text { (Fictitious) }\end{array}$ \\
\hline E1 & Psychologist & Psychotherapist & Camila \\
\hline E2 & Administrator & Real estate entrepreneur & Débora \\
\hline E3 & Administrator & Businesswoman in the aesthetic field & Mirela \\
\hline E4 & Administrator & Food Business Owner & Nair \\
\hline E5 & Administrator & Retail Entrepreneur & Tatiani \\
\hline
\end{tabular}

Source: prepared by the authors (2018).

\subsubsection{Ethical Inferences}

In order to maintain ethics in research, the following documents were presented: "Disclaimer of Responsibility for Use of the Speech for Research Purposes" and "Term of Guarantee to the Subject of Confidentiality and Anonymity". In addition, there was the guarantee of return to the subjects researched of the transcription of the statements collected.

\section{METHODOLOGICAL ASPECTS}

Sigmund Freud's Psychoanalytical Theory was chosen as the initial interpretative theory for this work, since it deals with assumptions about the codification of meanings through speech and physical and emotional expressions, observed through behaviors during the research process. 
INDEPENDENT JOURNAL OF MANAGEMENT \& PRODUCTION (IJM\&P)

http://www.ijmp.jor.br

v. 12, n. 4, May-June 2021

ISSN: 2236-269X

DOI: 10.14807/ijmp.v12i4.1351

For Godoi (2006), this is a methodology that seeks in interpretation and reciprocity between researcher and researcher, the understanding of the knowledge that subjects have about themselves. In this research, there was the elaboration of the researched people in relation to life experiences, memories, perceptions and significant events.

Still in relation to the analysis of data, Alonso (1998) and Godoi (2006), recommend that it be done in a structural way, by recovering the subject himself in the text, building the discourses according to a social reality and so that there is also a more pragmatic direct link of language and the social uses of argumentation, communication and tension, more or less conflicting. In this way, a possible concrete sense was constituted in its development, which attests to the objective of the research and the planned theme.

In terms of both discourse and context conceptions, the methodological-practical elements took into account the assumptions of the researcher, in this case, the generalist formation and systemic understanding of the world, work, individual and society (Conde, 2009). These guidelines were developed to be used in the qualitative research environment, whether in discussion groups, triangle groups or even in individual interviews.

Therefore, the choice of research technique used in this work was the clinical interview, which consisted in approaching the subjects by means of non-directed interviews, in which they intervened carefully to obtain the maximum in depth about their points of view (Creswell, 2013). During the clinical interview, there was almost no intervention and this often allowed the interviewee to have moments of reflection about what he was saying.

In addition, the individuals reported on issues related to the main theme, with the interviewer remaining the observation and brief link between their thoughts. In this technique, the silence of the researcher was of utmost importance, and varied according to the interjections and non-verbal expressions, such as head movements, gestures and small sounds (Creswell, 2013)

In the "interview records" item, audio recordings were made, so that later a reading, rereading and annotation could be made in a journal of the recorded audios. In these, we took into consideration the variations of voice tones, timbres, sounds and affective context. Following the orientation of the clinical-quitative investigations of (Turato, 2005) the approaches of apprehension of the information were based on the individuals, the personal experiences and the manifestations of the perceived experiences. The transcriptions reflect 
what the interviewees wanted to say at the time, relative and reliable to the phenomenon studied "Absence of Emotional Health".

It was also of utmost importance to preserve the anonymity of the interviewees, herein referred to as fictitious initials, in addition to the physical comfort during the interview, the mutual relationship of trust and the avoidance of a second interview, due to the possible loss of authenticity and consequently of originality (Turato, 2005). The following table summarizes the research methodology applied at work:

Table 3: Survey view

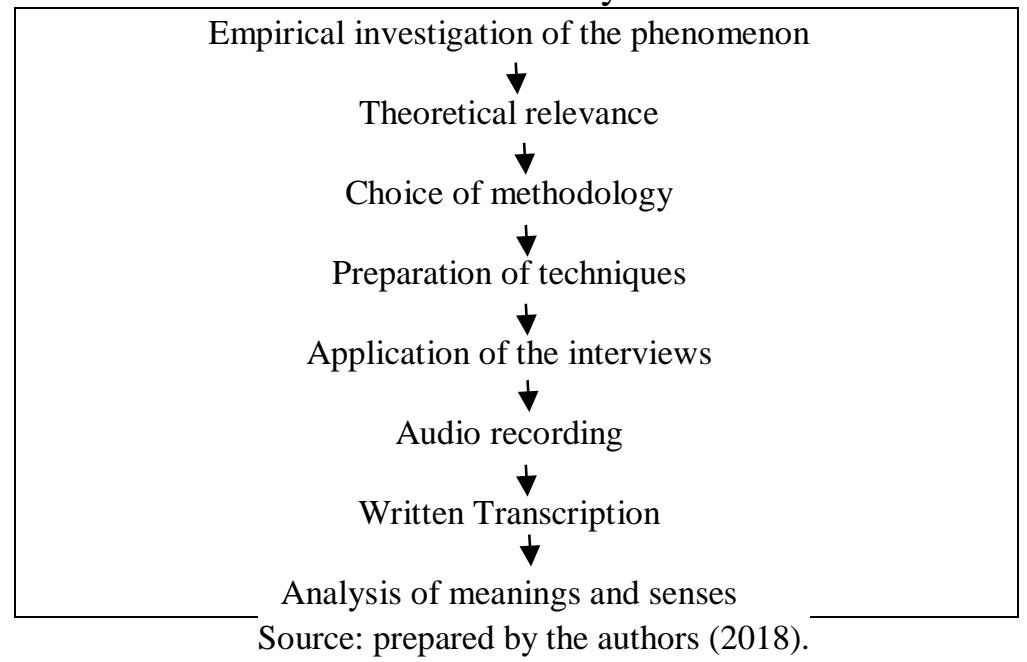

\section{RESULTS OF THE STUDIES}

In the attempt to propose a way of understanding the manifestations of the phenomena, the analyses were carried out to contribute to the identification of the positions that emerged throughout the interviews, and were presented through drawings and from the arguments and opinions expressed by the individuals researched (Mastella, 2015). It should be noted that the specific objectives described in the work were presented through an adaptation of analysis procedures developed and proposed by Silva (2010).

In this model, the psychodynamic connections common to all participants are presented and analyses of the participants' speech are made, and for this reason, psychoanalysis is used, considered the "speech interpretation theory" and, the "interpretative social analyses", tries to identify the social actors and link with the main themes, in the case of this work, with the narration of symptoms.

In this positioning map, we look for which symptoms were common to each participant, in an attempt to elucidate the Common Reference Process of Psychic Adoption - a concept 
DOI: 10.14807/ijmp.v12i4.1351

used by Dejours, which precedes the concept of Nexus, and which would occur as a mechanism of defense of the subject against a situation of illness (Dejours, 2009).

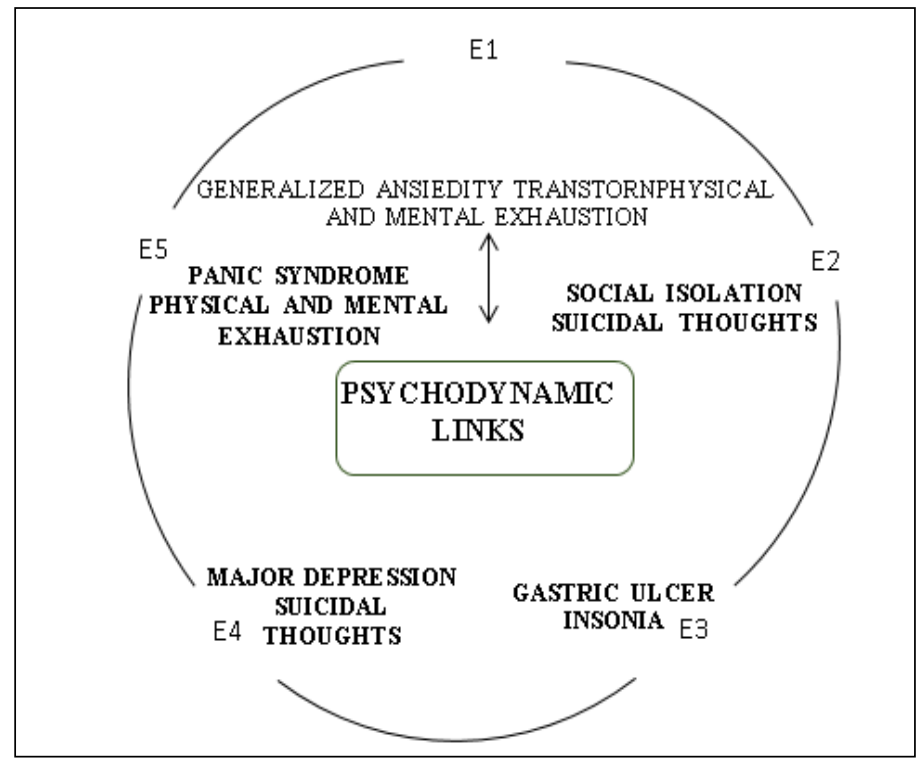

Figure 1: Map of participants' positioning in relation to the period of manifestation of symptoms throughout life Source: Adapted Dejours (2009).

It is noticeable that the five individuals interviewed present the Burnout Syndrome - (a disease characterized by professional exhaustion generated by a state of permanent tension and chronic stress that causes physical and psychological wear and tear) - as a Common Reference Process (Dejours, 1992) and that would lead them to medical withdrawal due to illness. In addition, the physical and emotional wear and tear experienced by the subjects in ambivalent situations of pleasure and suffering, resulting from work conditions and organization".

The objective of this graph is to relate the reports to the perception of the interviewees of how they felt when they experienced the process of Burnout Syndrome. The graph is disposed as to the degree of Self-perception in relation to Burnout and acceptance of the disease by the interviewees. In turn, the further to the left, the easier it seems for the individual to accept the problem.

These wears, besides being reported, were diagnosed by the doctors, who are the only professionals responsible for these purposes, and for the due withdrawals. It is noticeable that Camila, presents as Nexus, the Generalized Anxiety Disorder and the Physical and Mental Exhaustion. Débora, on the other hand, presented as Nexus, the Social Isolation and Suicidal Thoughts. 


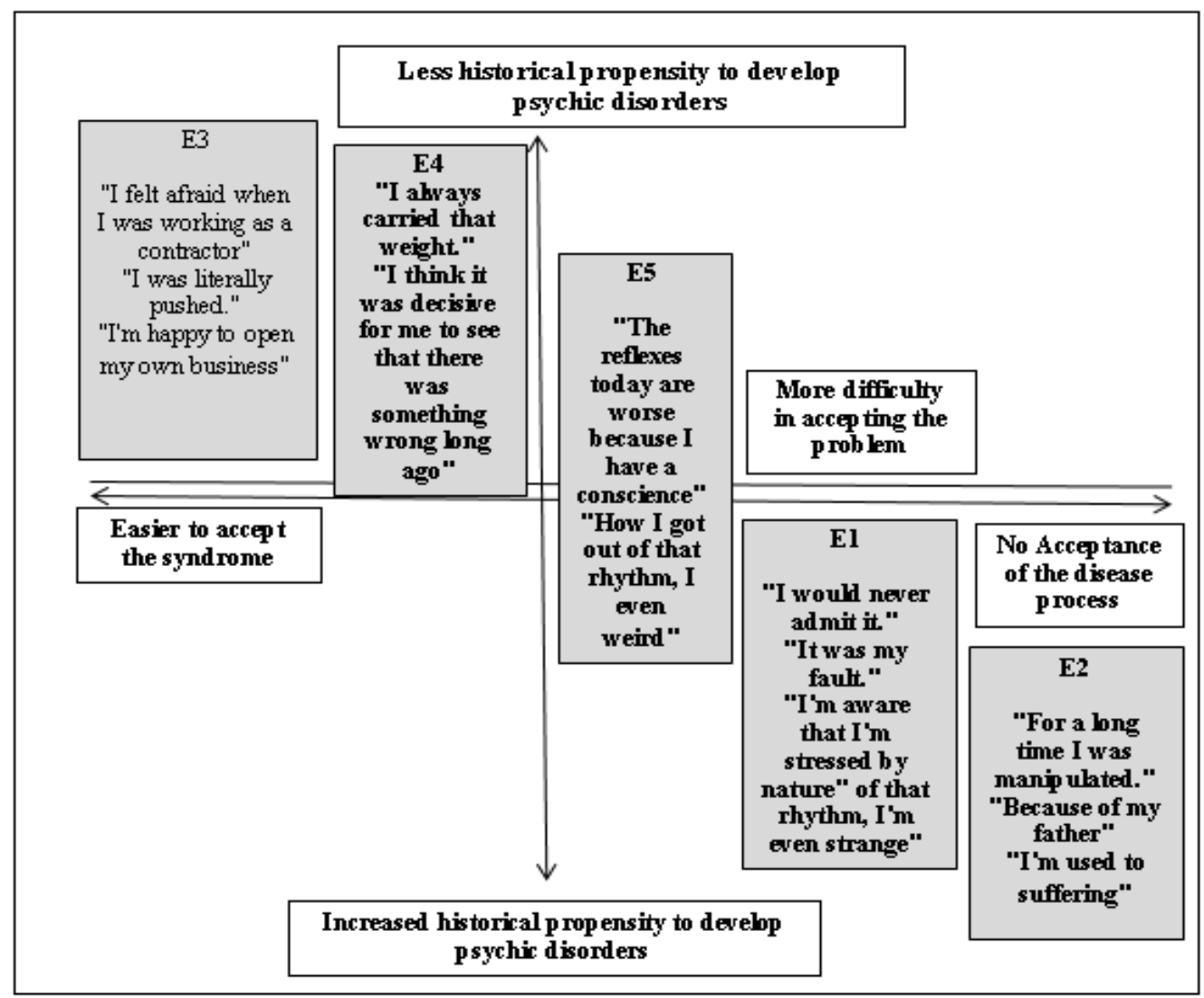

Figure 2: Self-perception in relation to Burnout (x) Level of difficulty in accepting the disease process

Source: prepared by the authors (2018).

The Psychodynamic Nexus presented by Mirela was through the symptoms of Gastric Ulcer and Insomnia. While for Nair, the complaints were those of Suicidal Thoughts and Depression. Finally, in this map, Tatiani presents as Nexus the Physical and Mental Exhaustion associated with Panic Syndrome.

It is also noticeable in the individuals researched that most physical symptoms appeared in adolescence and youth, while the associated psychic symptoms appeared in childhood; at the same time there is a list of the symptoms considered more severe such as stress, panic attacks, anxiety disorder and suicidal thoughts, appeared in adulthood and maturity. Another point that calls attention is the appearance of depressive pictures from a very early age, and one of the interviewees presented the association of anorexia and bulimia, even as a child.

For Abreu (2015), the most common causes of an emotional collapse would be chronic stress, generated by the environment in which one works, the separation of a partner, the death of a family member or affective relationship, for financial problems or even by managers with threatening characteristics, which would cause a constant feeling of failure to the individual. 
DOI: 10.14807/ijmp.v12i4.1351

The positioning of the participants in this map is done by excluding the symptoms that did not appear in the common relationship of the participants, precisely to facilitate the causal understanding between the Symptoms, Nexuses and Emotional Collapse. All the women interviewed reported physical, mental and emotional exhaustion; only Camila and Debora who did not present Panic Syndrome, Nair did not present physical problems, Tatiani did not develop Major Depression Disorder or Generalized Anxiety Disorder.

As we observed in the previous graph, the only point in common with the five interviewees is that they all reached the limit and mental, physical and emotional collapse. Thus, Mirela and Nair are the interviewees who accepted more quickly to be under emotional strain, while Mirela and Camila had more difficulty in accepting the problem. Deborah, on the other hand, denies all the time and attributes to others the fact of being emotionally and physically committed to the work.

These associative chains appear when the most colloquial language shows itself incapable of presenting analytically the dimensions that are at stake in a given phenomenon, appearing as a single representation, linked to several associative chains (Conde, 2009).

\section{FINAL CONSIDERATIONS}

In the scope of contemporary administration, it is up to managers to broaden the world vision in a systemic way, by contemplating and valuing the various areas of knowledge that are available and trying to solve these problems in organizations.

Management professionals are not responsible for judging which denominations are the most correct, but rather for understanding, how the symptoms reported would initiate the process of emotional illness, and how they would be interpreted because of the removal of individuals from organizations. Underpinned by the concepts of the individual, we believe that organizations need awareness of individual differences, how people act differently from each other and have unique emotions, needing to be sensitive enough to perceive and define their goals and objectives, and increasingly facilitate the formation of organizations with individuals with characteristics equivalent to their needs.

The contributions coming from this in all interviews made it possible to identify the mechanisms of perception of the symptoms of lack of emotional health in individuals. We observed that the beliefs brought since childhood, as well as the traumas that marked these individuals during adolescence and adulthood, open space for an important and enriching reflection: to what extent do organizations act as a reflection of the society in which we find 
DOI: 10.14807/ijmp.v12i4.1351

ourselves? Are people not reflecting an emotionally ill society in many ways and replicating these relationship models in organizations?

From the point of view of research practice, it was understood through this work that the elaboration of the content through speech can help in the elaboration of various elements that were stored in the interviewed individuals. We tried to establish links between lack of emotional health, dissatisfaction at work, stress, burnout syndrome and work absences.

One of the biggest problems found was finding people who wanted to participate in the research. It is known that these individuals would be confronted with the pain and emotional suffering that they went through at the same time as they would revive the feelings, emotions and memories of the traumas experienced in the organizations that worked through a process that could be more painful than pleasant.

We identified relationships between time away, moments in the life of these individuals when the first symptoms of psychic disorders appeared and the ability to accept the process of illness. The time away from work appeared to all interviewees as the final process in which it was no longer possible to bear the psychic, emotional, mental and physical symptoms.

It is noticeable that absenteeism for these individuals even worked as a defense mechanism, especially in the cases of the reports considered more serious, those with a history of propensity to develop diseases. It was observed that the quality of the relationships within the cited organizations, especially in relation to their direct superiors, caused the return of symptoms that were dormant.

It was also noticed that four of the five individuals who went through the process of absenteeism, today are owners of their own businesses, no longer having a direct relationship of superior subordination. While in the Freudian perspective, the diseases called psychopathologies would be the absence of psychic and emotional health, for medicine it would be worth the pathologies of behavior that can be measured, through the parameters and symptoms that present themselves.

However, it is inquired if the work was a consequence, cause or occurred due to people's pre-disposition to burnout, since all of them had serious precedents in relation to the factors "pressure", "time", "excess of responsibility". In these relationships, we could even say that these people could never have worked in these organizations; certain that they would have the subjective vulnerabilities are different in each person. It is possible to establish a symptomatic 
DOI: 10.14807/ijmp.v12i4.1351

pattern, but not the degree of psychic and emotional manifestations, the severity and speed that the symptoms manifest.

It is interesting to note that all the individuals participating in the research have moved away from work due to burnout syndrome, and show us that there was some kind of relationship with the theoretical concepts, from the psychoanalytical theory, the nexus and psychodynamics of work, the history of evolution of burnout syndrome and lack of emotional health.

It is important to emphasize that, even if the origins of psychic disorders have evolved from emotional triggers experienced in childhood or adolescence traumas, the organizational environments have contributed for these phobias to manifest themselves again, in different ways in each individual. It was also perceived through the reports that the process of aversion to companies that act in a traditional way and with a more rigid and controlling management was a reason for individuals with these profiles not to adapt, precisely because emotions give us valuable clues about the causes of psychic suffering.

We suggest new studies on the theme of absence of emotional health as part of a process for studies related to absenteeism, since in this area of organizational studies the relationship between the themes is considered in Brazil to be unprecedented. It is also necessary to increase the number of people interviewed, thus exploring more relationships between the themes addressed. If on the one hand, we have individuals who do not adapt to this reported organizational model, it is possible that others will be able to live together better, since each human being presents different degrees of complexity.

\section{REFERENCES}

Assunção, A. Á., et al. (2007). Recursos humanos e trabalho em saúde: os desafios de uma agenda de pesquisa. Caderno saúde pública, 23(2), 193-201.

Arnaud, G. (2012). The contribution of psychoanalysis to organization studies and management: An overview. Organization Studies. September.

Abraham, R. (1998). Emotional dissonance in organizations: Antecedents, consequences, and moderators. Genetic, Social, and General Psychology Monographs, 124(2), 229-246.

Adelman, P. K. (1995). Emotional labor as a potential source of job stress. In: Sauter, S. L., \& Murphy, L. R. (Eds.). Organizational risk factors for job stress. Washington, DC: American Psychological Association, 1995, 371-381.

Archer, M. (2000). Being human: the problem of agency. Cambridge: Cambridge University Press.

Ashford, B. E., \& Humphrey, R. H. (1993). Emotional labor in service roles: The influence of identity. Academy of Management Review, 18(1), 88-115.

Alves, R. (1996). Filosofia da Ciência. São Paulo: Brasiliense. 
Alves, M. (1996). Causas do absenteísmo: uma dimensão do sofrimento no trabalho. 165f. Dissertação (Mestrado em Sistemas de Gestão). Escola de Enfermagem, USP, São Paulo.

Barrett, R. (2000). Libertando a alma da empresa: Como transformar a organização numa entidade viva. São Paulo: Cultrix.

Bolton, S. C., \& Boyd, C. (2003). Trolley dolly or skilled emotion manager? moving on from Hochschild's Managed Heart. Work Employment and Society.

Brotheridge, C. M., \& Lee, R. T. (2002). Testing a conservation of resources model of the dynamics of emotional labor. Journal of Occupational Health Psychology, 7(2), 57-67.

Bryman, A. (1989). Research Methods and Organization Studies. London: Unwin Hyman.

Calheiros, P. R. V., \& Rodrigues, E. C. V. (2010). Psicologia Organizacional e as Ferramentas Usadas no Enfrentamento do Absenteísmo. Revista de Psicologia da IMED 2.2.

Chanlat, J. F. (Org.). (1994). O indivíduo na organização: as dimensões esquecidas. São Paulo: Atlas.

Conde, F. (2009). Análisis sociológico del sistema de discursos. Cuadernos Metodológicos 43. Madrid: Centro de Investigaciones Sociológicas (CIS).

Creswell, J. W. (2013). Qualitative Inquiry and Research Design. 3. ed. London: Sage.

Dejours, C., Abdoucheli, E., \& Jayet, C. (1994). Psicodinâmica do trabalho - Contribuições da Escola Djouriana à análise da relação Prazer, Sofrimento e Trabalho. São Paulo: Editora Atlas.

Dejours, C. (1992). A Loucura do Trabalho: Estudo de Psicopatologia do Trabalho. São Paulo: Editora Atlas.

Dejours, C. (2015). Psychopathology of Work: Clinical Observations. São Paulo: Karnac Books.

Diefendorff, J. M., \& Richard, E. M. (2003). Antecedents and consequences of emotional display rule perceptions. Journal of Applied Psychology, 88, 284-294.

Erickson, R. J., \& Wharton, A. S. (1997). Inauthenticity and depression: Assessing the consequences of interactive service work. Work and Occupations.

Fiker, R. (2006). O conhecer e o saber em Francis Bacon. São Paulo: Nova Alexandria.

Fredrickson, B. L. (2013). Updated thinking on the positivity ratio. American Psychologist, 68, 814-822.

Freud, S. (2012). O mal-estar na civilização. São Paulo: Companhia das Letras.

Freud, S. (1925). A denegação. In: Freud, S. Obras psicológicas completas de Sigmund Freud: edição standard brasileira. Vol. XIX. Rio de Janeiro: Imago.

Freudenberger, H. J. (1974). Staff burn-out. Journal of Social Issues, 30.

Godoi, C. K., Coelho, A. L., \& Serrano, A. (2014). Elementos epistemológicos e metodológicos da Análise Sociológica do Discurso: abrindo possibilidades para os estudos organizacionais. Organizações \& Sociedade, 21(70), 509-536.

Godoi, C. K., Melo, R. B., \& Barbosa, A. (2006). Pesquisa Qualitativa em Estudos Organizacionais - Paradigmas, Estratégias e Métodos. São Paulo: Editora Saraiva.

Hoschschild, A. R. (1979). Emotion work, feeling rules, and social structure. American Journal of Sociology, The University of Chicago Press. 
DOI: 10.14807/ijmp.v12i4.1351

Ito, J., \& Brotheridge, C. (2003). Resources, coping strategies, and emotional exhaustion: A conservation of resources perspective. Journal of Vocational Behavior, 63(18), 490-509.

Ipea. (2013). Mercado de trabalho: conjuntura e análise. Brasília: Ministério do Trabalho e Emprego/ Instituto de Pesquisa Econômica Aplicada.

Jennings, C. (2002). Strategic management: an evaluation of the use of three learning methods. The Journal of Management Development, Bradford, 21(9-10).

Kraft, U. (2006). Colapso Emocional e Esgotamento Total. São Paulo: Editora Artes Médicas.

Lacan, J. (1977). The subversion of the subject and the dialectic of desire in the Freudian. São Paulo: Editora.

Lacan, J. (1998). Situação da psicanálise e formação do psicanalista em 1956. In: Lacan, J. Escritos, Rio de Janeiro: Jorge Zahar.

Leiter, M. P., \& Harvie, P. L. (2013). Burnout among mental health workers: A review and research agenda. International Journal of Social Psychiatry, 42.

Linstead, S., \& Grafton-Small, R. (1992). On reading organizational culture. Organizational Studies, 13(3).

Maslach, C. (1997). The Truth About Burnout: How Organizations Cause Personal Stress and What to Do About It. USA: Josey Bass.

Mastella, A. S. (2015). O discurso feminino sobre o consumo de beleza na sociedade pósmoderna. TESE (Programa de Pós-Graduação em Administração). Universidade do Vale do Itajaí. 2015.

Marques, S. V. D., Martins, G. B., \& Cruz Sobrinho, O. (2011). Saúde, trabalho e subjetividade: absenteísmo-doença de trabalhadores em uma universidade pública. Cadernos EBAPE.BR, 9(Especial), 668-680.

Marcuse, H. (1981). Eros e Civilização: uma interpretação filosófica do pensamento de Freud. Rio de Janeiro: Zahar Editores.

Mauss, I. B. et al. (2011). Can seeking happiness make people unhappy? Paradoxical effects of valuing happiness. Emotion, 11, 807-815.

Maginn, M. D. (1996). Eficiência no Trabalho em Equipe. São Paulo: Nobel.

Mcgregor, D. (2002). Gerenciando o Lado Humano da Empresa. 1.ed. Rio de Janeiro: Qualitymark.

Minayo, M. C. M., Hartz, Z. M. A., \& Buss, P. M. (2000). Qualidade de vida e saúde: um debate necessário. Ciência Saúde Coletiva, 5, 7-18.

Ministério da Saude. (2007). Conferência Nacional de Saúde: relatório final. Brasília: Ministério da Saúde.

Mendes, A. M. et al. (2005). Validação do inventário de trabalho e riscos de adoecimento ITRA. In: Congresso Norte Nordeste de Psicologia, 4., Salvador. Anais... Salvador: Universidade Federal da Bahia.

Melo, J. N., \& Cosenza, O. N. (2015). O estresse nas empresas. IGT na Rede. Rio de Janeiro, 3.

Morgan, G. (2005). Paradigmas, metáforas e resolução de quebra-cabeças na teoria das organizações. Revista de Administração de Empresas, 45(1), 58-71, jan./mar. 
Neuman, K. (2003). The effects of organizational reengineeringon job satisfaction for staff in hospital social work departments. Social Work in Health Care, 36(4), 19-33.

Robbins, S. P. (2009). Fundamentos do comportamento organizacional. 7. ed. São Paulo: Prentice Hall Brasil.

Routledge, H. A. (2005). Emotional labor: an under-appreciated aspect of caring work. Nursing Inquiry.

Schein, E. H. (2002). Psicologia Organizacional. Rio de Janeiro: Prentice: Hall do Brasil LTDA.

Stein, M.B., \& Seed, et al. (2009). Establishing the neurologic basis of treatment in children and adolescents with generalized anxiety disorder. USA. The Official Journal of Psychiatry.

Souto, D. F. (1980). Absenteísmo, preocupações constantes das organizações. Temas de Saúde Ocupacional. Eletrobrás. Gridis.

Tamayo, A. (2000). Prioridades axiológicas e satisfação no trabalho. Revista de Administração. São Paulo: 35(2), 20-30.

Tracy, S. (2000). Becoming a Character for Commerce Emotion. Management Communication Quarterly, 14, 90-128.

Turato, E. R. (2005). Qualitative and quantitative methods in health: definitions, differences and research subjects. Public Health.

Waugh, C. E., \& Fredrickson, B. L. (2006). Nice to know you: positive emotions, self-other overlap, and complex understanding in the formation of new relationships. Journal of Positive Psychology, 1, 93-106.

Winslow, C. E. A. (1920). The untilled fields of public health. Science, 51(23).

Wichroski, M. R. (1994). The secretary: Invisible labor in the workworld of women. Human Organization, 53(1), 33-41.

Vieira, A., \& Goulart, I. B. (2007). Identidade e crise de identidade: reflexões conceituais. Curitiba: Juruá.

Wolfe, F., \& Cathey, M. A. (1983). Prevalence of primary and secondary fibrositis. J Rheumatol, 10(6), p. 965-968.

Wright, S. (1994). Culture in anthropology and organizational studies. In: Anthropology in organizations. London: Routledge.

Wright, T. A., \& Cropanzano, R. (1998). Emotional exhaustion as a predictor of job performance and voluntary turnover. Journal of Applied Psychology, 83(3), 486-493.

Zanatta, A. B., \& Lucca, S. R. (2015). Prevalência da síndrome de burnout em profissionais da saúde de um hospital oncohematológico infantil. Rev. Esc Enferm USP, 49(2), 253-260.

Yin, R. K. (2008). Case Study Research, Design and Methods. 4. ed., London: Sage Publications.

Zeithaml, V. A., Parasuraman, A., \& Berry, L. L. (2000). Delivering service quality: balancing customer perceptions and expectations. New York: The Free Press. 